Old Dominion University

ODU Digital Commons

Fall 2020

\title{
"The Most Glorious War Recorded in the British Annals": Portugal in British Figurations of the Peninsular War
}

Manuela Mourão

Old Dominion University, mmourao@odu.edu

Follow this and additional works at: https://digitalcommons.odu.edu/english_fac_pubs

Part of the European History Commons, and the Literature in English, British Isles Commons

Original Publication Citation

Mourão, M. (2020). "The most glorious war recorded in the British annals": Portugal in British Figurations of the Peninsular War. Studies in Romanticism, 59(3), 299-327. https://doi.org/10.1353/srm.2020.0017

This Essay is brought to you for free and open access by the English at ODU Digital Commons. It has been accepted for inclusion in English Faculty Publications by an authorized administrator of ODU Digital Commons. For more information, please contact digitalcommons@odu.edu. 


\section{MANUELA MOURÃO}

\section{"The most glorious war recorded in the British annals": Portugal in British Figurations of the Peninsular War}

"T HE MOST GLORIOUS WAR RECORDED IN THE BRITISH ANNALS," AS ROBERT Southey described it in the dedication of his History of the Peninsular War, ${ }^{1}$ the conflict that brought together Portugal, Spain, and Britain against Napoleon's armies between I807 and I8I4 was a dominant preoccupation of the British public in general, and of the first generation of Romantics in particular. $^{2}$ Many critics have shown the extent to which the Iberian uprising against the tyranny of Napoleon galvanized the British people, united the British nation, and afforded Southey, Wordsworth, and Coleridge a renewed opportunity to sympathize with the cause of freedom after their disenchantment with the course of the French Revolution. ${ }^{3}$ As well, many studies have demonstrated

I. Southey, History of the Peninsular War, 3 vols. (London: John Murray, I823), I:iv.

2. There is critical consensus that the definitive history of the Peninsular war is Sir Charles Oman's seven-volume History of the Peninsular War (Oxford: Clarendon, I902-30). For a more succinct but thorough account see Jan Read's War in the Peninsula (London: Faber and Faber, 1977).

3. For discussions of how the Spanish cause, as it became known, generated a great feeling of solidarity in Britain, and brought the Lake poets back in touch with their early ideals see Joselyn M. Almeida, "Introduction: Of Windmills and New Worlds," in Romanticism and the Anglo-Hispanic Imaginary, ed. Joselyn Almeida (New York: Rodopi, 20I0); David Bromwich, "Vicarious Feeling: Spanish Independence, English Liberty," in Concerning the Convention of Cintra: A Critical Edition, ed. Simon Bainbridge, W. J. B. Owen, and Richard Gravil (Penrith: Humanities E-Books, 2009); Deirdre Coleman, "Re-Living Jacobinism: Wordsworth and the Convention of Cintra," The Yearbook of English Studies I9 (1989): I44-6I; David Eastwood, "Robert Southey and the Meanings of Patriotism," Journal of British Studies 3I, no. 3 (July I992): 265-87; Tom Duggett, "Wordsworth's Gothic Politics and the Convention of Cintra," The Review of English Studies, New Series 58, no. 234 (April 2007): I86-2I I; Richard Gravil, "Wordsworth as Partisan," in Concerning the Convention of Cintra: A Critical Edition; Georgina Green, "The People and the Poet Redeemed: William Wordsworth and the Peninsular Uprising," ELH 79, no. 4 (20I2): 935-62; Patrick Vincent, "Sleep or Death? Republicanism in The Convention of Cintra," in Concerning the Convention of Cintra: A Critical Edition.

Studies in Romanticism 59 (Fall 2020): 299-327 | (C) 2020 Trustees of Boston University 
how the conflict and its discursive representations aided in shaping Britain's identity by fomenting its image as an enlightened nation that championed freedom: Linda Colley, for example, has explored the connections between military conflict with the French and the formation of British national identity; ${ }^{4}$ Kathryn Chittick has highlighted the role of the periodical press in establishing an atmosphere that led to the country's re-examination of its national identity vis à vis its position on liberty; ${ }^{5}$ Joselyn M. Almeida, Deirdre Coleman, Gavin Daly, Mary A. Favret, and Diego Saglia have discussed the impact of literary representations, and shown how imaginative literature and non-fictional personal accounts both shaped and reflected contemporary perceptions of Iberia by Britons. ${ }^{6}$ Saglia in particular has explored in great depth the ideological configurations of the representations of Spain in British Romantic texts. ${ }^{7}$ In turn, and corroborating a point also made by Favret's earlier work, Daly has examined the personal accounts of British soldiers' experiences in Spain and Portugal in letters, memoirs, and diaries to demonstrate how this wealth of written records inevitably shaped the British reading public's perception of the events and of the peoples of the Iberian Peninsula. ${ }^{8}$

4. Colley, Britons: Forging the Nation, 1707-1837 (New Haven, CT: Yale University Press, 1992).

5. See Chittick, The Language of Whiggism: Liberty and Patriotism, 1802-1830 (London: Pickering \& Chatto, 20IO). Her analysis stresses the importance of the convergence of "literature and politics" (34) at that historical moment in renewing attention to the question of "the modern idea of British freedom" (35). She reads the juxtaposition of Francis Jeffrey's review of Charles James Fox's History of James II and Henry Brougham's article "Mr. Whitbread's Letter on Spain" in the July I808 issue of the Edinburgh Review as instrumental in shaping the country's perspective on its own identity. As Chittick writes, there was an "imaginative excitement generated by Spanish popular resistance and decisive British action" (34) - a combination that helped shape a discourse that elevated Britain because of its embrace of Spain's uprising.

6. See Almeida, "Introduction: Of Windmills and New Worlds"; Coleman, "Reliving Jacobinism"; Daly, "A Dirty, Indolent, Priest-Ridden City: British Soldiers in Lisbon During the Peninsular War, I808-I8I3," History 94, no. 4 (October 2009): 46I-82; Daly, The British Soldier in the Peninsular War: Encounters with Spain and Portugal, 1808-1814 (New York: Palgrave, 20I3); Favret, "War Correspondence: Reading Romantic War," Prose Studies I9, no. 2 (1996): I73-85; Saglia, “'O My Mother Spain!': the Peninsular War, Family Matters, and the Practice of Romantic Writing," ELH 65, no. 2 (Summer I998): 363-93; Saglia, "Nationalist Texts and Counter-Texts: Southey's Roderick and the Dissensions of the Annotated Romance," Nineteenth-Century Literature 53, no. 4 (March 1999): 42 I-5I; Saglia, Poetic Castles in Spain: British Romanticism and Figurations of Iberia (Amsterdam: Rodopi, 200o); Saglia, "War Romances, Historical Analogies and Coleridge's Letters on the Spaniards," in Romantic Wars: Studies in Culture and Conflict, 1793-1822, ed. Philip Shaw (Aldershot, 2000).

7. See Saglia, “'O My Mother Spain!”; Poetic Castles in Spain; and "War Romances."

8. In "War Correspondence: Reading Romantic War," Favret maintains that "war in the Romantic period [was] an epistolary production" (I73), and that "letters shaped the experience of war" for both the soldiers writing them and the people reading them 
The profusion of contemporary records about, and present-day analyses of, the Peninsular War notwithstanding, there is an issue that has remained unaddressed in all this commentary: the tendency to focus primarily on Spain and marginalize Portugal. Be it parliamentary discussions about the war, or polemical debates in the periodical press, or even poetry and prose directly or indirectly inspired by the British enthusiasm for the cause of liberty, again and again consideration of the plight of the Iberian peoples involved in the struggle against the armies of Napoleon privileges Spain and sidelines Portugal, sometimes subsuming it into its Iberian neighbor. This essay argues that this sidelining of Portugal is symptomatic of the country not quite fitting into the narrative of Britain as a champion of freedom that began to take shape in the earliest moments of the conflict as the British people embraced the cause of Spain. To do so, the essay first highlights contrasting British attitudes toward Spain and Portugal at the beginning of the war, and reads Portugal's failure to kindle British imagination in the same way Spain did as symptomatic of Britain's perception of the country as unworthy of freedom. It then furthers this argument by analyzing the discursive privileging of Spain in discussions of the conflict, beginning with the influential essays of I808 and I 809 that were part of the periodical wars between the Edinburgh Review and the Quarterly Review, and continuing with prose commentary about the conflict written by the Lake poets-whose intense involvement in the debates about it is well recorded. Wordsworth's Cintra pamphlet is the central focus in this section because despite the poet's avowed intention to affirm how grievously Britain wronged Portugal by accepting the terms of the Convention of Cintra, his elevation of Spain as the true emblem of the spirit of freedom becomes paramount. The essay closes with a brieflook at poems by Robert Southey and Felicia Hemans inspired by, or responding to, the Peninsular war, as instances of how widely-read contemporary poetry also reflected and furthered Britain's focus on Spain. Indeed, while both Southey and Hemans were knowledgeable about Portuguese language and literature, and both translated Portuguese poetry, some of their most successful poems of the period were works that contributed to the romance of Spain as a mirror of "the modern idea of British freedom." As we will see, Hemans specifically celebrated the bravery of contemporary Spanish fighters against Napoleon in England and Spain (1808), in "War-Song of the Spanish Patriots" (I8I2), and in "Guerilla Song" (I8I8). In addition, both poets produced poetry that featured heroic Iberian figures culled from Spanish history: Southey in Chronicle of the Cid (I808) and Roderick,

back home (173). In "A Dirty, Indolent, Priest-Ridden City" and The British Soldier in the Peninsular War, Daly offers compelling evidence that this was indeed the case.

9. Chittick, Language of Whiggism, 35 . 
the last of the Goths (I8I4); Hemans in "Songs of the Cid" (I823). These poems, then, further illustrate the systematic discursive privileging of Spain traced here; inevitably, they also contributed to furthering it by solidifying British perceptions of the cultural difference between Spain and Portugal that were already in place.

\section{Spain vs. Portugal}

During the early stages of the French invasion of the Iberian Peninsula, the plight of the Spaniards, betrayed both by their king and by Napoleon, undeniably justified the romantic aura that surrounded their popular uprising, the Dos de Mayo, which so strongly resonated in Britain. But the situation of Portugal was no less dramatic: with their sovereign in exile in Brazil (in compliance with strong British pressure ${ }^{\mathrm{ro}}$ and under French occupation for several months, the Portuguese people rose up against the forces of Napoleon in June I808 (a month after the Dos de Mayo uprising in Spain). With the help of British troops under the command of Sir Arthur Wellesley, they then defeated the French in the battle of Vimeiro, on August 2I, I808. Since the first engagement of the British army in the Peninsular war was in Portugal, and since their victory led to the signing of the infamous Convention of Cintra (whose terms so favored the defeated French army and so blatantly disrespected Portuguese sovereignty that it led to an official inquiry into the conduct of the British generals involved), it is curious that in the fourth quarter of $\mathrm{I} 808$ and in I809, British discussions of the affairs in the Peninsula so noticeably privileged "the Spanish cause" over the events in Portugal. Granted, during the second half of I808, the daily press reported on Sir Arthur Wellesley and his forces in the Battle of Vimeiro, as well as on the Convention of Cintra. And both The Edinburgh Annual Register and The New Annual Register, or, General Repository of History, Politics, and Literature of $\mathrm{I} 808$ dedicate chapters to detailing the history of the British engagement in Portugal and to the controversy surrounding the signing of the Convention. Still, even if the events in Portugal during I800-I809 were well covered by the newspapers, a quick search of the British Newspaper Archive reveals that Spain was discussed much more often. Most importantly, the lengthy, more influential opinion essays during this period,

IO. As Martin Robson has shown, Britain's pressure on Portugal to put its fleet under British protection and send the royal family to exile in Brazil in the event of a French invasion actually included the threat to take the Portuguese fleet by force and attack Portuguese colonies if they refused to comply. See Robson, "British Intervention in Portugal, I793-I808," Historical Research 76 (February 2003): 93-I07, I00-I02. This is but one example of how Britain's long-time colonialist attitude toward Portugal translated into a sense of entitlement to direct Portuguese affairs. Especially felt throughout the war years, this attitude often neutralized Portuguese initiative, keeping them from making choices that were not sanctioned (or even initiated) by the British. 
including those by the Lake poets, focused on the significance of what was happening in Spain. ${ }^{11}$ And if it is possible to justify the discursive emphasis on Spain as partly a result of that country's strategic importance for Britain, it should be remembered that Portugal was also strategically central: "Lisbon was the British gateway to the war" ever since the decision, early in I809, "to use Portugal, and Lisbon in particular, as the central base of their war effort." Moreover, control of the Tagus naval base was invaluable to British interests. ${ }^{13}$ Therefore, explaining the repeated sidelining of Portugal in terms of the two Iberian countries' relative importance to British economic and military interests would oversimplify the issue. A more nuanced understanding of Britain's relationship with Portugal at the time is required. This means entertaining the possibility that discursive representations of the Peninsular War were inflected as much by political circumstances as by the rhetorical imperative of coupling Britain's lofty role as a preeminent supporter of freedom (and the attendant promulgation of the feeling of national unity that flourished in I808) with its position as a supporter of Spain — which, unlike Portugal, was seen by Britons as a worthy representative of the broader cause of European freedom.

\section{Spain in the British Romantic Imagination}

Spain's figuration in Romantic letters is a good entry point for verifying the asymmetry in the power of the two Iberian countries to spur the British imagination. In "“O My Mother Spain!”' Diego Saglia stresses that because of its resistance to Napoleon and its new alliance with Britain, Spain seemed to have overcome its "otherness" in the eyes of the British people, their common investment in a nationalist ideology uniting them in fellow feeling. ${ }^{14}$ In Poetic Castles, he attempts to offer a more nuanced understanding of the ideological function of Spain in the British Romantic imagination by mapping out how "imaginary fictions and referential representations combine" to create an idealized view of the country. ${ }^{\text {Is }}$ In noting Britons' widespread interest in discussing all things relating to Spain and the Peninsular War, he points out that Spain was in the peculiar position of being discursively appropriated by opposite sides of the British political divide, with each side seeing Spain in a radically different way,

II. As mentioned above, in his Tract on the Convention of Cintra (I809), Wordsworth certainly denounces the British generals' actions and decisions vis à vis Portugal. Nonetheless, a great deal of his passionate address focuses on the Spanish cause. And Coleridge, in his Letters on the Spaniards (1809-10)—a work which, he writes, he "should be proud to consider ... as an Appendix" (77) to Wordsworth's Cintra tract-hardly mentions Portugal. His entire analysis focuses on British attitudes toward Spain. He defends the Spaniards from British criticism due to disappointment with their conduct in the war.

I2. Daly, The British Soldier, 47

I3. Robson, "British Intervention in Portugal," 93.

I4. Saglia, "'O My Mother Spain!", 363.

I5. Saglia, Poetic Castles, I3. 
but as a uniform entity nonetheless, defined by its resistance to oppression. ${ }^{\mathrm{I} 6}$ In time, as the conflict with Napoleon progressed, so did Britain's discursive appropriation of Spain: initially, it served to unify opposing political factionsColeridge once described the Spanish Cause as the vehicle that "made us all once more Englishmen by at once gratifying and correcting the predilections of both parties"; ${ }^{17}$ eventually, though, "party politics . . . [and] national interests . . . became central" again, ${ }^{18}$ and Spain became a source of political disagreement. Ultimately, Saglia argues, "Spain was edited out of the histories of a war that was increasingly turned into a British affair even as it was developing" point that highlights the extent to which Britain's involvement in the Peninsular war rhetorically affirmed its own idealized identity through what Saglia calls "the transitivity of [Spain's] nationalist ethos." ${ }^{\text {"o }}$ But for a while, in work after work of imaginative literature, the British Romantics focused on Spain in what Saglia termed "a specifically British exercise in displaced self-analysis."

We will later consider some of Robert Southey's and Felicia Hemans's poems as specific instances of how Spain was figured in British Romantic literature. For now, Saglia's insights can help us understand the prominence of the idea of Spain in the Romantic period and, though indirectly, suggest at least one reason why Portugal-Britain's oldest ally—was regularly overlooked in discussions of the Peninsular war: as he writes, "Spain was adopted by Holland House as a testing ground of Whig ideology." ${ }_{22}$ As a major Whig cultural circle with a strong focus on Spain, Holland House made a systematic effort to disseminate an interpretation of the events in Spain as proof of the country's "awakening from the retrograde political culture of the Bourbon monarchy and ... [having] a natural propensity to the English political model." ${ }^{23}$ To construct this version of Spain for British consumption, Holland House "stimulated an intensification of fictional and non-fictional representations of Spain modelled according to idealized views of this country as devoted to progress, institutional change and modernization." ${ }^{24}$

I6. Saglia, Poetic Castles, Io.

17. Quoted in Saglia, Poetic Castles, I2.

18. Saglia, Poetic Castles, 20.

I9. Saglia, Poetic Castles, 24.

20. Saglia, Poetic Castles, 65 .

2I. Saglia, Poetic Castles, 64.

22. Saglia, Poetic Castles, 26.

23. Saglia, Poetic Castles, 26. Lord Holland's attempts to influence Spanish affairs are well known. Saglia mentions that "Holland's personal collaborator drew up a proposal for a constitution that was sent to Spain with a copy of the Red Book containing the procedures of the British Parliament" (Poetic Castles, 27); moreover, he advised the Spaniards to "refashion their Cortes in the form of the Westminster assembly" (Poetic Castles, 27).

24. Saglia, Poetic Castles, 24. Lord Holland and Lady Holland themselves wrote books about Spain and Spanish literature (Saglia, Poetic Castles, 27); both also wrote travel diaries of their trips to Spain and Portugal. 
Within this context, then, one reason for Portugal's peripheral stand in early British discourse on the Peninsular war begins to emerge: Spain is given center stage because its position as an "other," which it traditionally shared with Portugal in particular, and with the European south more generally, ${ }^{25}$ has been systematically transformed by sustained efforts at recasting it as a progressive nation invested in, and capable of, freedom in the British model. Portugal's "otherness," on the other hand, remained unchanged, anchored by Britain's long-standing colonialist attitude toward its oldest ally, which it continued to view as backward and deferential, and thus a poor object for the affirmation of British enlightened enthusiasm. Lord Holland's personal feelings, registered in his I808-9 diary of a trip to Portugal, are emblematic of his country's marked difference in attitude toward the two Iberian countries. ${ }^{26}$ As John Clarke argues in his Preface to a Portuguese translation of that diary, the trip tested Lord Holland's Whig convictions, for he came to believe that unlike Spain, Portugal might be best served by a government based on Enlightened Despotism principles due to what he read as its people's submissive character:

Nothing can more strongly mark the difference between the Portuguese and Spanish character than their conduct on such occasions and however tyrannical the government of Spain may have been, no magistrate would at any time have dared to interfere with the people of Castile in the manner to which the Portuguese submit with chearfulness [sic] on the slightest occasion from the Juíz de Fora of any miserable village. ${ }^{27}$

Lord Holland's opinion of the Portuguese national character openly expressed here echoes generalized British perceptions of it registered in countless other travel accounts before and after. Perhaps the most famous example was the direct comparison Byron made between the Spaniards and the Portuguese in Childe Harold's Pilgrimage: "For proud each peasant as the noblest Duke:/ Well doth the Spanish hind the difference know/ 'Twixt him and Lusian slave, the lowest of the low." ${ }^{28}$ But, seen as he was as "the living

25. For a genealogy of southern European peoples' enduring position of inferiority within western Europe see Roberto Dainotto, Europe (in Theory) (Durham, NC: Duke University Press, 2007).

26. See Lord and Lady Holland, and John Allen, Três Diários de Viagem: Portugal em 1808-1809, notes and introduction by José Baptista de Souza (Casal de Cambra: Caleidoscópio, 2OII).

27. Clarke, Preface to Três Diários de Viagem, I2.

28. Byron, Childe Harold's Pilgrimage. The Poetical Works of Lord Byron (London: Oxford University Press, I946), I86, canto I, stanza 33, lines 7-9. The attitude Byron's poem exemplifies is aptly captured by Wordsworth's daughter, Dora Wordsworth Quillinan, when she writes in her journal: "'Our old and faithful ally,' Lusitania, revolts at the airs of affectionate contempt with which she is patronized by England." 
embodiment of the Whig tradition,"29 Lord Holland's acknowledgment, at the very moment of the Iberian struggle against Napoleon, that he would have respected the Portuguese more had they seemed less submissive helps explain why, at this time, subsuming Portugal into Spain under the term Iberian (or simply privileging Spain in textual figurations of the Peninsular war) helped sustain the idealized image of Britain as a progressive champion of freedom: with Portugal sidelined, British reluctance to believe that the country was as worthy of freedom as Spain was de-emphasized, as was the attendant latent contempt for the Portuguese national character. Eventually, British national feeling toward Spain shifted back, beginning with the losses at Coruña and Talavera, and then with King Ferdinand VII's repudiation of the liberal Constitution in I8I4. But at this early moment in the conflict, it remained strongly positive, so the focus on Spain remained, and the Iberian country continued to capture the attention of many of the most famous Romantics..$^{\circ}$ As we will see, the period's resulting literary legacy of works celebrating Spain and its past heroes far outweighs that on Portugal.

Spain in the Reviews I808-9

The three well-known articles that arguably established the focus of national debates on the subject of Britain's support for the cause of liberty were two essays in the Edinburgh Review entitled "A Letter from Mr. Whitbread to Lord Holland, on the present Situation of Spain" (July I8o8), and "Don Pedro Cevallos on the French Usurpation of Spain" (October I808)-both by Henry Brougham-as well as another in the Quarterly Review entitled "Affaires d'Espagne" (February I809), written by George Ellis and George Canning, which directly responded to the "Don Cevallos" review. ${ }^{31}$ These

Quillinan, Journal of a Few Months Residence in Portugal, and Glimpses of the South of Spain, 2 vols. (London: Edward Moxon, I847), I:viii.

29. Clarke, Preface to Três Diários de Viagem, II.

30. Debate on the Peninsular War in the periodical press remained strong until I8I2, when, Saglia maintains, "the momentum of Spanish patriotic victories was past ... and British public opinion was absorbed by other issues of domestic and national policy" (Romantic Castles, 23). For an overview of the brief resurgence of British interest in Spain's struggle for freedom in I8I4 and I823, and of the connection between that enthusiasm and British national politics, see also Ian Haywood, "The Spanish 'Revolution' in Print and Image," in Spain in British Romanticism, ed. Saglia and Haywood (New York: Palgrave McMillan, 2018).

3I. Brougham, "Don Pedro Cevallos on the French Usurpation of Spain," The Edinburgh Review I3 (October I808): 215-34; [Ellis and Canning], "Affaires d'Espagne," The Quarterly Review I, no. I (February I809): I-I9. As noted earlier, these and subsequent periodical essays systematically constructed an image of Britain as a defender of liberty and affirmed this idealized identity even as they participated in a gradual subsuming of Portugal into Spain, and of the French invasions of the Iberian Peninsula into "the Spanish cause." Their cultural and rhetorical power made them especially suited to perform this ideological move. Besides the texts under discussion here (i.e., the articles in 
texts garnered more than usual attention and aroused more than usually passionate responses, ultimately setting the tone of the narrative of British identity as being shaped and illustrated by its support of the Spanish cause. Each of them seeks to form readers' opinions on the political position of England in relation to Spanish affairs, and they were instrumental in facilitating the identification of the Peninsular war with the Spanish cause. This is the more noteworthy as the Portuguese uprisings were happening throughout the month of June $\mathrm{I} 808$, precisely as the parliamentary debates mentioned in the July I 808 Edinburgh Review essay-which arguably started it all-were taking place.

The subject of "A Letter from Mr. Whitbread to Lord Holland, on the present Situation of Spain" was, as the reviewer put it, "of such general importance, and the public are, in our humble apprehension, running so far out of the right course in their views of it, that we avail ourselves of this opportunity to say a few words upon it." ${ }^{2}$ In essence, the letter attempted to explain why Mr. Whitbread, having initially sought to dissuade Mr. Sheridan from bringing up the issue of Spain during the Parliamentary session of June I3, I808, was now convinced that England ought to assist the Spaniards "with all the means in our power" (435) because "all over Spain an unexampled spirit of resistance to the enemy has burst forth" (434). The reviewer supports this position, and explicitly and systematically articulates why there is no inconsistency in having condemned England's war with France after the French Revolution and in supporting it now, after France's aggression toward Spain. He stresses that France has unequivocally become the aggressor and tellingly points out that because Spain has finally overthrown its long-time submissiveness to its former ally, the Spaniards are now worthy of admiration and deserving of British help. By contrast, Portugal's simultaneous uprising against France, its parallel struggles, and its own righteous position in the same conflict fail to arouse comparable British admiration-likely because its position as a submissive ally of England dependent on English forces is actually reinforced by their resistance to France-and thus remain unreferenced.

Brougham's essay ends by predicting that Spain will ultimately be unable to prevail against Napoleon: "Greatly as we think of the Spaniards, their enemy is at the head of half a million of the best soldiers in the world"

The Edinburgh Review and in The Quarterly Review, as well as Wordsworth's pamphlet on the Convention of Cintra, part of which was published in two installments in the Courier on December 27, I808 and on January I3, I809), Coleridge's Letters on the Spaniards (published as "Letters to the Editor" in the Courier, December I809 to January I8Io), and Southey's History of Europe (in the Edinburgh Annual Register for I808 and I809, and published in I8IO and I8I r respectively) are also examples of this move.

32. Brougham, "A Letter from Mr. Whitbread to Lord Holland, on the present Situation of Spain," Edinburgh Review I2 (July I808): 433-34. All subsequent quotations from Brougham's essay will be cited parenthetically in the text by page number. 
(439); thus, "the odds are turned against them" (440) despite "the popular spirit, now so gloriously prevalent all over Spain" (44I). But his pessimistic view of the Spanish odds against the French does not change the rhetorical elevation of the country to the center of the conflict: "Every thing, then, hinges upon Spain," he stresses (444). He may, as Chittick notes, "perhaps go ... too far in ... dilating on the reasons why [the French army] has so far been undefeated," but he does so in an attempt to critique the Tory government for its "incompetence born of nepotism," which allows him to further emphasize Spain's worthiness for having overcome that particular scourge..$^{33}$

The following number of the Edinburgh Review ran Brougham's essay "Don Pedro Cevallos on the French Usurpation of Spain" (October I808), where, as Chittick points out, the writer "went on to develop [the same] strain of Whiggish pessimism." ${ }^{44}$ That pessimism led in part to the strong backlash against the article: Tories read the predictions of Spanish defeat as "pro-Napoleonic propaganda" and were outraged..$^{35}$ Famously, there were dramatic reactions to the article by some well-known readers of the Edinburgh Review: the Earl of Buchan kicked his copy out into the street, while Sir Walter Scott canceled his subscription; ${ }^{36}$ others reportedly "cleared their libraries of the abominable journal, and then fumigated the shelves." 37 As Carnall and others have reiterated, these reactions were against what many perceived as the article's open endorsement of Jacobinism, especially in Brougham's clever rhetorical move of equating support for the Spaniards with tacit sanction of revolution:

Whoever has wished well of them, feels intimately persuaded, that he has been espousing the popular side of the greatest question of the present day; that he has been praying most fervently for the success of the people against their rulers; that he has, in plain terms, been, as far as in him lay, a party to revolutionary measures.

But this rhetorical move, following the assertion that regardless of the outcome of the conflict, Spain would be "a lesson to all governments" (220) and instrumental in "rais[ing] the spirit of the middle and lower classes, both in this country and the rest of Europe" (223), also constructs Spain as the sole focus of British sympathy. In addition, it reiterates its role as the main

33. Chittick, Language of Whiggism, 36, 37.

34. Chittick, Language of Whiggism, 37.

35. Chittick, Language of Whiggism, 37.

36. See Geoffrey Carnall, Robert Southey and His Age: the Development of a Conservative Mind (Oxford: Clarendon, I960), 97; see also Coleman, "Reliving Jacobinism," I45.

37. Coleman, "Reliving Jacobinism," I 45. 
instrument in the re-kindling of British hopes for the triumph of freedom. For even though the French had been defeated in Portugal in August I808 in the battles of Roliça and Vimeiro, the Portuguese soldiers, perceived as submissive because under British command, offer no comparable capacity for galvanizing British enthusiasm.

The outrage caused by the Don Cevallos article in the Edinburgh Review led to the creation of the Quarterly Review " "not as a corollary, but in contradiction to it." "38 In "Affaires d'Espagne," the opening article of its first issue (February I809), Ellis and Canning question the accuracy of interpretations of Spanish actions being disseminated by the press, pointing out that "the Spaniards have been, and are acting in conformity to their peculiar character, from motives, and with objects of their own, and ... to view their conduct through the medium of our opinions, and feelings, and prejudices, is to pervert and distort it." 39 When defending the government's decisions to send troops to Portugal, the reasons they invoke emphasize the difference in Britain's relationship to Spain and Portugal, and represent it as determined in part by the very different character of the two people-even though political and strategic reasons were also necessarily at play. In answering those who "demand . . . the reason of locking up our army in the south-west corner of Portugal, when the great battle was fighting in the north-east extremity of Spain" (I3), they clarify that the Spaniards themselves felt that "by the expulsion of Junot from Portugal we [the British] should render them the most essential service in our power" (I4). Moreover, they stress that the Spaniards had asked only for "a supply of arms and ammunition, [and] disclaimed any wish of receiving further assistance" (I2), adding that "it is evident from the whole public conduct of the Spaniards that they came to their great conflict resolved to work out their own emancipation by their own efforts, not from a romantic disdain of foreign aid, but from a deep conviction that their situation precluded them from any such reliance" (I2). In short, to Ellis and Canning, the Spaniards' is the clear-sighted perspective of an independent people, strong in their self-reliance.

By contrast, their essay paints an unflattering picture of Portugal as submissive and ineffective: while the writers do not hide the strategic importance Lisbon had for Britain (I 4), their emphasis is on Portugal as timid and dependent on Britain for survival: "The Portuguese government were the victims of their fidelity to us; and we were bound in honor, though not under any direct engagement, to re-conquer Portugal if possible; and we

38. William Hazlitt, qtd. in Green, "People and the Poet Redeemed," 936.

39. [Ellis and Canning], "Affaires d'Espagne," 4-5. All subsequent quotations from Ellis and Canning's essay will be cited parenthetically in the text by page number. See Green, "People and the Poet Redeemed" (935-37) for a detailed analysis of the central argument in the essay. 
did so" (I3)..$^{\circ}$ And while the article questions the wisdom of several British decisions, the critique of those decisions maintains the rhetorical pattern that anchors the whole essay: casting Portugal as helpless, Spain as heroic, and Britain as fully committed to the cause of liberty by gratifying "at the earliest possible moment, the wishes of the Spaniards" (I7).

The British urge to gratify Spanish desires stressed here is particularly revealing since it reminds us that it was not, in fact, until Spain-a recent enemy - requested that British forces be committed to rid Portugal—an old ally-of the French occupation that British ministers decided to send the army to Portugal. ${ }^{4}$ Till then, in part due to having determined that the Portuguese were too passive and would be unable to defend themselves-even when evidence showed they were fully committed to improving their war-making abilities ${ }^{42}$ - Britain had only been interested in safeguarding their commercial interests by ensuring the Portuguese royal family be sent to Brazil, and the Portuguese navy be placed under their custody "for safekeeping." 43

The essay ends with the reiteration of Ellis and Canning's belief in Spain's ultimate success - not because its army is a match for Napoleon's, but because of the admirable spirit of the Spanish people:

we shall not despair of Spanish emancipation... . [T] hat the whole active population of a great country, in which the strongest passions of the human heart have been excited almost to madness, can be terrified into quiet and permanent submission is, we think, extremely improbable and contrary to all experience.

(I8-I9)

Thus, while the Quarterly Review challenges the Edinburgh Review's assertions regarding the nature - and likely outcome-of the Spanish uprising, both periodicals, as the analysis above demonstrates, anchor their construction

40. Southey's historical account in the Edinburgh Annual Register of I809 (Edinburgh: John Ballantine, I8I I) also allows us to infer that because of the hierarchical imbalance of the relationship, in many British minds, helping Portugal did not resonate in the same way helping Spain did: the former was a duty Britain was honor-bound to perform, whereas the latter was a desire. His commentary on parliamentary discussions of the events of March-April I809 illuminates this difference (see chap. 29, esp. 693-703).

4I. Later, as Wordsworth vehemently denounces, the British generals in charge of the signing of the Cintra Convention show an analogous higher level of respect to their enemies (the defeated French generals) than to their current Portuguese allies.

42. Robson, "British Intervention in Portugal," 97.

43. Robson, "British Intervention in Portugal," 98. Again, as Robson's thorough account of British intervention in Portugal at the time stresses, Britain had actually been "prepared to resort to hostile measures" if Portugal were to refuse those demands (I06). 
of Britain as a champion of freedom on a depiction of Spain and its people as having an indomitable spirit capable of inspiring Britons with an analogous feeling. The struggle against Napoleon is systematically represented as involving mainly France, Spain, and England, while Portugal is figured as hardly of consequence.

\section{The Lake Poets and the Peninsular War}

The intense engagement of the Lake poets with the French invasions of the Iberian Peninsula comes through in their correspondence. Southey often refers to his "Spanish fever" in his private letters; 44 and in a June I3, I808 letter to Coleridge, he openly places his tenuous hopes for European freedom on the events in Spain: "if Europe is to be redeemed in our days, you know it has always been my opinion that the work of deliverance would begin in Spain." 45 The poet does offer a brief account of events in Portugal, namely a report of the misery experienced by the people of Lisbon (especially the women of the families who are forced to accept French officers and soldiers as lodgers) but his thoughts immediately return to the plight of Spain: "were I minister, I would send half the regular army without delay to Spain." ${ }^{\prime 6}$ By the end of the letter, we find a striking example of how easily the idea of Portugal being subsumed into Spain comes to the mind of Southey, one of the British writers best acquainted with both countries:

This is the moment for uniting Spain and Portugal; and the greater facility of doing this in a commonwealth than in a monarchy would be reason enough for preferring that form of government were there no other. Portugal loses something in importance and in feeling by being incorporated in the Spanish monarchy; it would preserve its old dignity by uniting in a federal republic, - a form which the circumstances of Spain more especially require. ${ }^{47}$

In these lines, Southey expresses his wish for such subsuming to become literal: Portugal should be incorporated into Spain with only a nod to preserving "its old dignity" by doing it in a Commonwealth.

Southey's opinion was not singular: a similar argument about Portugal can be found in the November I, I809 issue of the London Review, in the essay "On the Spanish Revolution" (a review of, among other works, Wordsworth's tract on the Convention of Cintra), where the author comments on Portugal's role in the decay of Spain from its ancient glory:

44. Saglia, "Nationalist Texts," 422.

45. Southey, Life and Correspondence of Robert Southey, ed. Charles Southey (New

York: Harper and Brothers, I85I), 235.

46. Southey, Life and Correspondence, 236.

47. Southey, Life and Correspondence, 236. 
"Portugal, which united to Spain, could give it no strength, when torn from it added to its weakness." ${ }^{48}$ As he predicts Spain's future resurgence, he adds: "Portugal will become subject as it ought; it is the excrescence of a healthy body, if not a part of Spain." 49 And in the most prominent prose pieces about the Peninsular events the Lake Poets published between I809 and I8Io-Wordsworth's Tract on the Convention of Cintra (I809), ${ }^{50}$ Coleridge's Letters on the Spaniards (I809-IO), ${ }^{51}$ and Southey's History of Europe in the Edinburgh Annual Register of I808 and I809 (I8IO-II) ${ }^{52}$-even when the acknowledged intention was to refer to the whole Peninsula, the main focus was on Spain and "the Spanish cause," the rhetorical strategies employed in the texts all but overlooking Portugal.

The earliest of these works, Wordsworth's pamphlet on the Convention of Cintra, best captures the Lake Poets' passionate disappointment when the revolutionary fervor of their youth, which had been briefly rekindled by the uprising in the Peninsula, was tamped down by the signing of the treaty. Wordsworth wrote it, in Southey's words, "'to ease his heart", ${ }_{53}$ after Lord Lonsdale succeeded in preventing a public meeting planned by Wordsworth, Southey, and Coleridge, ${ }^{54}$ at which Wordsworth had intended to speak about "the indignity of the convention." Hew Dalrymple on behalf of Portugal is well known: after the defeat at Vimeiro on August 2I, I808, Junot, the French general, negotiated extremely favorable concessions from the British generals; namely, the French army and all its possessions (horses, equipment, and plunder from Portuguese churches, museums, and private homes) were to be transported back to France in British ships, at British expense. No Portuguese officers were consulted as the treaty was negotiated, although it included conditions that directly impacted Portuguese sovereignty. These terms were so shocking, they led to a storm of reactions and an official inquiry.

48. Henry Crabb Robinson, "On the Spanish Revolution," London Review 2, no. 4 (Nov. I, I809): 242.

49. Crabb Robinson, "On the Spanish Revolution," 242.

50. William Wordsworth, Tract on the Convention of Cintra [Published 1809]. With two Letters of Wordsworth Written in the Year 1811 Now Republished. With an Introduction by A. V. Dicey (London: Humphrey Milford, I9I5).

5I. Samuel Taylor Coleridge, Letters on the Spaniards in Essays on his times in the Morning Post and the Courier, in The Collected Works (London: Routledge \& Kegan Paul, I978).

52. Southey, The Edinburgh Annual Register for 1809 (Edinburgh: John Ballantyne, I8II). Southey later used the material from these chapters in the History of the Peninsular War (1827-I832).

53. Quoted in Peter Manning, Reading Romantics: Texts and Contexts (New York: Oxford University Press, 1990), I75.

54. Chittick, Language of Whiggism, 40; Green, "People and the Poet Redeemed," 938. 55. Manning, Reading Romantics, I74. 
As has been noted, the Cintra pamphlet is the longest of all the poet's prose works, ${ }^{56}$ with "a contentious critical history. . . . [and] by no means easy to read." ${ }^{77}$ Chittick captures the text's essence in an apt summary: "In the Convention of Cintra Wordsworth notes that the government's wars 'against liberty' [the American Revolutionary war and the French Revolution] and 'for liberty' [the Spanish wars] had in fact shown the same moral insensibility to the spirit of the common people." ${ }^{8} 8$ For Wordsworth, the very treaty stood as evidence of that moral insensibility. In his words, it "reversed everything:- favour and honour for their enemies - insult for their friends." ${ }_{99}$ And while the pamphlet pursues a plurality of political and philosophical perspectives already explored by many critics, I want to focus on what this particular statement reveals regarding Wordsworth's awareness and condemnation of what I have been arguing is at the core of the sidelining of Portugal and the emphasis on Spain in British discussions of the Peninsular conflict - that is, Britain's inability to view its oldest ally as anything but a deferential dependent, on whose behalf all decisions could be made without concern for its sovereignty. But I also want to highlight that this awareness was not sufficient to keep the poet from eventually placing the same discursive emphasis on Spain I have been tracing - nor from ultimately endorsing, like Southey, a literal subsuming of Portugal into Spain as the solution for the problems of the Iberian Peninsula.

56. Chittick, Language of Whiggism, 40; Brian Folker, "Wordsworth's Visionary Imagination: Democracy and War," ELH, 69 (2002): I68.

57. Gravil, "Wordsworth as Partisan," 26. For a succinct overview of the main points Wordsworth makes in the pamphlet, as well as of some of its most salient critical interpretations, see Gravil's "Wordsworth as Partisan." Generally, critics note the apparent political and philosophical tensions of the work, and then offer suggestive readings that seek to resolve them-often by connecting the issues raised in the pamphlet with specific Wordsworth poems, or else by reading them in the context of other contemporary works. See, for example, Simon Bainbridge, "A Self-Defeating Campaign," in Concerning the Convention of Cintra: A Critical Edition; Chittick, Language of Whiggism; Coleman, "Reliving Jacobinism"; Duggett, "Wordsworth's Gothic Politics"; Folker, "Wordsworth's Visionary Imagination"; Green, "People and the Poet Redeemed"; Manning, Reading Romantics; and Susan Valladares, "For the sake of illustrating principles': Wordsworth, the Convention of Cintra, and Satirical Prints," European Romantic Review 24, no. 5 (2013): 53 I-54.

58. Chittick, Language of Whiggism, 40. Her stress on Wordsworth's emphasis on the people as his reason for hope (4I) reiterates a point made by several other critics: Coleman has argued that the pamphlet reveals Wordsworth's great belief in the people ("Reliving Jacobinism," I46); Gravil has highlighted how much "[t] he text expresses an ardent self-vindication as a consistent man of the people" ("Wordsworth as Partisan," 22); and Green has termed the tract the poet's "most successful and unequivocal commitment to "the people"" ("People and the Poet Redeemed," 939).

59. Wordsworth, Tract on the Convention of Cintra, I75. All subsequent quotations from the Tract are cited parenthetically in the text. 
Early into his essay, after detailing the reconciliation between Spain and Britain as a high point in the re-awakening of British enthusiasm for the cause of liberty, Wordsworth realizes that he has been speaking only of Spain, and hastens to clarify:

I have indeed spoken rather of the Spaniards than of the Portuguese; but what has been said, will be understood as applying in the main to the whole Peninsula. The wrongs of the two nations have been equal, and their cause is the same: they must stand or fall together.

The Spanish cause is the Portuguese cause, he maintains, because the two nations have suffered the same wrongs. As he recapitulates the events that led to the signing of the Convention, he keeps a double focus on both nations, describing the plight of Portugal and quoting the Spaniards' address to the Portuguese in recognition of their suffering: "Your lot is, perhaps, the hardest ever endured by any people on earth" (28). He then quotes from Junot's proclamation to the Portuguese people, stressing the French general's threats and his undisguised glee in blaming Portuguese rebelliousness for French violence (3I), and follows with a notice of the French address to the Spaniards where similar accusations of the people as rebels are made (32). In this section, Wordsworth's emphasis is on the similarity of the troubles of the Iberian nations, as well as on the need for them to stand together. He quotes from another address of the Spanish Junta of Seville to Portugal in order to foreground it: "“Come then, ye generous Portugueze, and unite with us"' (40). The section ends with a direct address to the readers where he exalts both countries: "the Spanish and Portuguese nations stand upon the loftiest ground of principle and passion" (43), he writes; and he urges the British public to "not suffer . . . those sympathies to languish which a few months since were so strong" (43).

Commentary on the Convention itself, arguably the most crucial segment of the pamphlet, follows. Necessarily, the focus shifts to the interaction between the British and the Portuguese. Wordsworth's analysis starts precisely by noting the glaring anomaly that is the complete exclusion of Portugal from the negotiations, as well as from the narratives of the engagement with the French that led to the victory and to the signing of the treaty:

Pleasure was damped in the minds of reflecting persons by several causes. It occasioned regret and perplexity, that they had not heard more of the Portuguese. They knew what the people had suffered, and how they had risen. ... Why then, it was asked, do we not hear more of those who are at least coequals with us, if not principals in this contest? They appeared to have had little share in either engagement . . . and, 
while the French were abundantly praised, no word of commendation was found for them. Had they deserved to be thus neglected?

In speculating about the possible reasons for this exclusion, Wordsworth touches on the hierarchical imbalance in the relationship between British and Portuguese generals (47), on Sir Arthur Wellesley's "want of sympathy with the just feelings of his injured Ally" (48), which he attributes to "general habits of contemptuousness" (48), and on his lack of "any fellow-feeling with the people whom he had been commissioned to aid" (49). The British generals' contempt for the Portuguese, their allies, and their marked consideration for the French, their enemies, shock the poet; yet they are hardly surprising within the historical context of the relationship between Portugal and Britain: consistently characterized by an asymmetry of power, that relationship, at the time of the French occupation of the Peninsula, was necessarily at its most imbalanced. Implicitly, in the eyes of the British, Portugal had already been excluded as an agent in the conflict, or such a treaty could never have been signed. Wordsworth implies as much when he writes:

We enter the Portugueze territory as allies; and, without their consentor even consulting them, we proceed to form the basis of an agreement, relating — not to the safety or interests of our own army — but to Portugueze territory, Portugueze persons, liberties, and rights,- and engage, out of our own will and power, to include the Portugueze army, they or their Government willing or not, within the obligation of this agreement.

Or when he insists:

In whatever circumstances Portugal had been placed, the paramount right of the Portuguese nation, or government, to appear not merely as a party but a principal, ought to have been established as a primary position, without the admission of which, all proposals to treat would be peremptorily rejected.

$(74-75)$

As he begins to analyze individual articles of the treaty, he continues to register shock that "we, instead of triumphantly displaying our power towards our enemies, have ostentatiously exercised it upon our friends, reversing here, as every where, the practice of sense and reason" (73); and he condemns the fact that British flags, rather than Portuguese ones, were hoisted over Portuguese forts (76). He reiterates his moral outrage at each article of the 
Convention, stressing the astonishing deference the British generals showed towards the French, and the dishonorable position in which the British army was placed by the many unwarranted concessions they made to a defeated enemy, "conciliatory even to abject submission where we ought to have been haughty and commanding" (73). As well, he foregrounds the extent of the disrespect for Portuguese rights and feelings entailed by the Convention, and objects to the exclusion of Portugal by quoting the Portuguese General, Bernardim Freire, regarding the conditions in the treaty that guaranteed the safety of those Portuguese who had collaborated with the French (87).

Ultimately, though, despite protesting the exclusion of Portugal, Wordsworth does not seem to grasp-or else is unable to acknowledgethe extent to which the signing of the Convention, in completely nullifying Portuguese agency, is symptomatic of British colonialist attitudes that signify well beyond Sir Hew Dalrymple's and Sir Arthur Wellesley's obliviousness to Portuguese sovereignty. Indeed, the benevolent paternalism that underlies his lament that the Portuguese position is weak and that the duty of the British generals was to "foster and encourage them" (73) is also a symptom of those attitudes, unconsciously though they be held. In his vigorous defense of the Portuguese character- "But the Portuguese are a brave people-a people of great courage and worth!" (93), he writes - and in his sustained denunciation of the wrongs the Portuguese suffered due to the British signing of the Convention, Wordsworth demonstrates his admirable commitment to defending the weakest party. But he also constructs a colonialist image of British moral and philosophical superiority that further emphasizes Portuguese dependence and submission. The failure of British duty that he has been systematically highlighting in the text is, in his eyes, unforgiveable first and foremost because of Britain's lofty reputation:

For we have, throughout Europe, the character of a sage and meditative people. Our history has been read by the degraded Nations of the Continent with admiration, and some portions of it with awe; with a recognition of superiority and distance. ... We have been looked up to as a people who have acted nobly . . . as a people among whom philosophers and poets, by their surpassing genius - their wisdom-and knowledge of human nature, have circulated, — and made familiar-divinely-tempered sentiments and the purest notions concerning the duties and true dignity of individual and social man in all situations and under all trials.

A stronger depiction of British moral and national superiority can hardly be imagined. Rhetorically, it emphasizes how abhorrent the signing of the Convention was, how much of an anomaly Wordsworth believes it represents. 
But it also betrays the same intense British colonialist feeling that is at the root of the disregard for Portugal's sovereignty he is denouncing.

From this passage, Wordsworth transitions to a section where he discusses how strongly the British people condemned the treaty, and he decries the government's refusal to nullify it (97-I06). His tone becomes increasingly philosophical as he tries to extrapolate from these events a general inference about fear and courage, the human soul and the human race, and the higher aspirations this conflict awakened in the British people (II3-I4). This shift in emphasis shows a corresponding shift in the focus of the poet's examples. Spain, again, becomes the center of Wordsworth's concern and the source of his illustrations of heroic deeds, of people spurred to courage and action through awareness of the true worth of the objective (I I6-I9). And he enumerates "further works of these united powers" (I 20) in Seville, in Madrid, in Andalusia, in Valencia, in Asturias, in Salamanca (I2I) - none in Portugal. The argument he builds in this section is that in signing the Convention, the British dealt a terrible blow to the Spaniards and their hopes:

we had the power to act upon the most sacred letter of justice.... We had power to give a brotherly aid to our allies in supporting the mighty world which their shoulders had undertaken to uphold; and, while they were expecting from us this aid, we undermined - without forewarning them - the ground upon which they stood. The evil is incalculable; and the stain will cleave to the British name as long as the story of this island shall endure.

In this passage, Wordsworth further attempts to strengthen the point he has consistently sought to argue: that the two Iberian nations have suffered the same wrongs. To that effect, he represents the signing of the treaty as equally injurious to Spain as it was to Portugal.

But while throughout the pamphlet Wordsworth maintains this view that the plight of both nations is the same, that their wrongs are the same, they are in fact not the same-at least not at the hands of the British. Undeniably, both nations endured very similar ignominies inflicted by the armies of Napoleon and his commanders. But only the Portuguese had their agency matter-of-factly denied by their oldest allies. The Convention of Cintra could only be signed because the British generals never thought of Portugal's agency at all. In overlooking the significant difference in British attitudes towards the two countries, especially at this early moment of the conflict, Wordsworth also contributes to the representation of Spain as the central party in the Iberian conflict against Napoleon-not 
in that he discursively sidelines Portugal, but in that he disregards the importance of the particularity of its dependence on, and submission to, Britain. Thus, despite the vehemence of his condemnation of the attitudes of those in power, by never acknowledging British resistance to believing that Portugal was as worthy of freedom as Spain, he shores up the notion of Britain as a nation that upholds the highest moral principles, regardless of how far its statesmen and military commanders may stray from them. Wordsworth's statement, toward the end of his commentary, that "the two nations of the Peninsula should be united in friendship and strict alliance; and, as soon as it may be effected without injustice, form one independent and indissoluble sovereignty" (I64) recasts the discursive oversight of Portugal I have been tracing into a wish for a literal subsuming of the country into Spain, "effected without injustice" (I64). This wish problematically devalues Portugal's national independence in an essay so centrally concerned with decrying its violation. ${ }^{60}$

\section{Buttressing the "Iberian Text": Felicia Hemans and Robert Southey"}

This analysis of the discursive processes through which British accounts of the French invasions of the Iberian Peninsula privileged Spain over Portugal, as well as of the influence of a few key texts in fomenting this tendency, has so far focused on non-fiction prose commentaries. Because these texts constitute some of the earliest and historically most influential contemporary commentaries on the Iberian countries' struggle against Napoleon, and because their glorification of Spain and neglect of Portugal cannot be considered a mere linguistic expedient or an oversight, they have weighed centrally in my argument. Given that a similar neglect of Portugal is found in British Romantic poetry celebrating the spirit of freedom unleashed in resistance to Napoleon, a brief discussion of the contemporary work of two widely-read British poets with strong knowledge of, and personal connections to, Portugal and its culture-Robert Southey and Felicia Hemans_-can further illustrate how naturalized the

6o. For an interpretation of Wordsworth's brand of revolutionary ideology see Benjamin Kim, Wordsworth, Hemans, and Politics, 1800-1830: Romantic Crisis (Lewisburg, PA: Bucknell University Press, 2013), esp. 78. Even allowing that Wordsworth makes a distinction between freedom and national independence, the latter is still a central concern of the pamphlet. Thus, this contradiction should be read as another instance of a reflexive sidelining of Portugal, so naturalized as to have become unnoticeable.

6I. In using the expression "Iberian Text," I acknowledge both Nanora Sweet's expression "Mediterranean text" in "The bowl of liberty: Felicia Hemans and the Romantic Mediterranean" (PhD. Diss., University of Michigan, I993), and Saglia's "Spanish text" in his Poetic Castles, while also affirming that I am specifically concerned with Romantic poetic figurations of Spain that contribute to naturalizing the sidelining of Portugal in representations of the Iberian conflict. 
celebration of Spain (and concomitant devaluing of Portugal) had become in representations of the Iberian conflict.

Above, we have already noted the depth of Southey's focus on the events in the Peninsula-what he called his "Spanish fever." From I808 and I 809 on, besides working on chronicling the war for the Edinburgh Annual Register, Southey was also indirectly engaging with it in poetry celebrating legendary Spanish heroes: Chronicle of the Cid (I808), and Roderick, the Last of the Goths (I8I4). ${ }^{62}$ Both poems resulted in part from his having been steeped in the study of Portuguese and Spanish language and literature for years, starting with two residencies in Portugal and travel in Spain before the Peninsular War-the first in I795-96, the second in I800-I80I. In I797, Southey had published the journal of his first trip, Letters Written During a Short Residence in Spain and Portugal, With Some Account of Spanish and Portuguese Poetry, where, in his typical antiquarian fashion, he included sections on the language and poetry of Spain and Portugal, as well as his own translations of Spanish and Portuguese literature. His expertise in the culture of the two countries is well known, but his literary output on Portugal in particular, a result of the years he spent preparing to write the never-completed History of Portugal, is arguably a testimony of his superior knowledge of that country's history. ${ }^{63}$ Yet, when it came to deciding on a subject for poetry celebrating the nationalist feeling underlying the resistance to Napoleon in the Peninsula, Southey chose to cull from the chronicles of Spain's heroic age. The Chronicle of the Cid is in part a translation of the sixteenth-century version of the original medieval Castilian text, and in part an amalgamation of different sources. ${ }^{64}$ Ernest BernhardtKabisch reads the poem as "a good first step to rally the spirit of patriotism" which, he believes, Southey would fully achieve in Roderick, the Last of

62. Interestingly, and further proof of the particular attention to Spain in the contemporary British periodical press, Southey's Chronicle of the Cid was reviewed in the famous inaugural issue of the Quarterly Review - the same issue where Ellis and Canning published their review essay "Affaires d'Espagne" discussed above.

63. I have examined part of Southey's literary output on Portugal in more detail in "Robert Southey on Portugal: Travel Narrative and the Writing of History," Nineteenth-Century Contexts 37, no. I (2015): 43-60. Here, I wish only to point out that his knowledge of Portugal's history and culture was superior even to his knowledge of Spain's. For comprehensive studies of Southey's life and work see John Dennis, ed., Robert Southey: the Story of his Life Written in his Letters (Boston: D. Lothrop, I887); Adolfo de Oliveira Cabral, ed., Southey e Portugal, 1774-1801: Aspectos de uma Biografia Literária (Lisbon: P. Fernandes, I959); W. A. Speck, Robert Southey: Entire Man of Letters (New Haven, CT: Yale University Press, 2006).

64. For commentary on Southey's deft interweaving of his sources see Walter Scott's review of the poem, "Chronicle of the Cid Rodrigo Diaz de Bivar, the Campeador, from the Spanish, by Robert Southey," Quarterly Review I, no. I (February I809): I34-35. See also Saglia's "Robert Southey's Chronicle of the Cid: Spain as a Textual Archive and an Intervention Zone," Cuadernos de Ilustración y Romanticismo I8 (20I2): 44. 
the Goths- "an epic of foundation ... a song about the passage of the old, feudal order, and about the birth of a new one out of the holocaust of foreign domination." ${ }^{\circ}$

Both poems were very successful. About Chronicle of the Cid, Coleridge wrote, in a letter to Humphrey Davy:

I have read few books with such deep Interest, as the Chronicle of the Cid. The whole scene in the Cortes is superior to any equal Part of any Epic Poem, save the Paradise Lost-me saltern judice. The deep, glowing, yet ever self-controlled, Passion of the Cid-his austere Dignity so fiercely harmonizing with his Pride of loyal Humility — the address to his Swords . . . are beyond all ordinary Praise. ${ }^{66}$

As for Roderick, the last of the Goths, Southey himself considered the poem "the best which I have done and probably the best that I shall do," and even Byron- no friend to Southey-declared it "the first poem of the time" and "as near perfection as poetry can be." ${ }^{.77}$ In the end, Roderick saw a total of four editions and was the most financially successful of Southey's epics. ${ }^{68}$

Undoubtedly, the success of these two poems owes much to contemporary interest in the romance of Spain. ${ }^{69}$ With Chronicle of the Cid, Southey offered readers the first English version of the medieval Castilian text, part of the effort of " "cultural translation' of Spain and its civilization into nineteenth-century British culture" that Saglia discusses, and what he considers "the most outstanding and influential contribution to British Hispanism." 70 With Roderick, the last of the Goths, Southey produced "the most sustained Romantic representation of the Roderick material, and a complex metrical tale built around a national theme." ${ }^{\prime 1}$ Ultimately, both texts exemplify the sustained attention Southey paid to Spain and its legendary heroes in his contribution to the literary debates on the nation that were spurred by the Iberian conflict; by contrast, and most importantly for this argument,

65. Bernhardt-Kabisch, Robert Southey (Boston: Twayne, I977), I30, I3I. Roderick, the last of the Goths was one of three near-simultaneous treatments of the legend of Roderick, which included Sir Walter Scott's The Vision of Don Roderick (I8II) and Walter Savage Landor's Count Julian (1812).

66. Coleridge, Collected Letters of Samuel Taylor Coleridge, ed. E. L. Griggs (1956-7I), III:I36. Reprinted in Lionel Madden, ed., Robert Southey: the Critical Heritage (Boston: Routledge, I972), I28.

67. Both Southey and Byron are quoted in Bernhardt-Kabisch, Robert Southey, I43.

68. Madden, Robert Southey, I75,

69. For a reading of these works as British Romantic iterations of the "Spanish text" obliquely referring to the British nation see Saglia's Poetic Castles.

70. Saglia, "Robert Southey's Chronicle of the Cid," 39.

7I. Saglia, Poetic Castles, 82. 
they also underscore Southey's choice to forego writing poetry featuring Portuguese heroes or Portuguese myths of nation foundation, despite his great knowledge of Portuguese history and literature, where such myths were readily available..$^{2}$

While no other contemporary British writer could claim to be as much of an expert in Portuguese and Spanish languages, literatures, and cultures as Southey, Felicia Hemans also studied those languages, and translated some Iberian poetry published in the volume Translations from Camoens and Other Poets (I8I8). Part of her interest in the Peninsular War was personal: she had two brothers who served in the army (one of them in Portugal under the command of Sir Thomas Moore), and she became engaged to an army officer who was sent to Spain in $1809 .{ }^{73}$ But it is clear from her poetry about the conflict that she also shared in the nation's general enthusiasm for England's role in the Iberian struggle, and that she was especially moved by Spain's patriots. In England and Spain (I808), a 300-line poem celebrating Spain's resistance, she "represented England's engagement as a renewal of the nation's libertarian traditions," 74 and attributed to Spain the loftiest feelings of heroism and virtue, ${ }^{75}$ while mentioning Portugal only in passing. Unsurprisingly, given her young age, reviewers noted "evidence of premature publication"; still, they praised the poem's technical skill, and her subsequent works were reviewed increasingly seriously. ${ }^{76}$

72. The Portuguese epic of nation foundation and expansion is Camoens's The Lusiad. Southey only translated some of Camoens's lyric poetry, but he would have read the epic either in Portuguese or in English translations already available. See George Monteiro, The Presence of Camões: Influences on the Literature of England, America, and Southern Africa (Lexington, KY: University Press of Kentucky, I99I).

73. In fact, she did invoke her family connection to justify taking up such an unfeminine and controversial subject in her poetry. See, for example, Diego Saglia "Epic or Domestic?: Felicia Hemans's Heroic Poetry and the Myth of the Victorian Poetess," Rivista di Studi Vittoriani 2, no. 4 (1997): I25-47; Juan Sánchez, "'England and Spain' and 'The Domestic Affections': Felicia Hemans and the Politics of Literature," Studies in Romanticism 53, no. 3 (Fall 20I4): 399-4I6. For an essay on British women poets' interest in writing about the Peninsular War see Paula Alexandra Guimarães, "The Rescue of Lusia by Albion: Representations of Portugal in British Women's Peninsular Poetry," Revista de Estudos Anglo-Portugueses 25 (2016): I 47-66.

74. Gary Kelly, "Introduction," in Felicia Hemans: Selected Poems, Prose, and Letters (Peterborough; Ontario: Broadview, 2002), I9-20.

75. Sánchez, “"England and Spain,”" 404.

76. Stephen C. Behrendt, "Felicia Hemans's Early Reception," in Felicia Hemans: Reimagining Poetry in the Nineteenth Century, ed. Nanora Sweet and Julie Melnyk (New York: Palgrave, 200I), 98. Hemans's popularity grew steadily until she became the most widely read nineteenth-century woman poet writing in English. See Kelly, "Introduction" in Felicia Hemans, is. 
Hemans continued to address the theme of Spanish patriotism in The Domestic Affections, and Other Poems (I8I2), specifically in "War-Song of the Spanish Patriots," a poem where the speaker invokes Castilian and Andalusian patriots in a call to resistance against "oppressive might" (line 3); and in the I8I8 volume Translations from Camoens and Other Poets, specifically in "Guerrilla Song," an original poem also based on the story of a Spanish patriot who returned home to find no hero's welcome, "For the spoilers had passed, like the poison-wind's breath,/ And the loved of his bosom lay silent in death" (lines II-I2). The translations from Camoens included in the volume were of his lyric poems only. Indeed, just like Southey, Hemans reached for Spanish heroes, not Portuguese ones, for her poems indirectly celebrating resistance to Napoleon in the Peninsula. ${ }^{77}$ "Songs of the Cid," a series of poems first published in the New Monthly Magazine and then included in The Siege of Valencia . . . with Other Poems (I823), were, as she noted, "ballads culled from [Spanish] tradition," some also paralleling certain episodes in Southey's Chronicle of the Cid. ${ }^{78}$

Given Southey's and Hemans's popularity, their poetry celebrating Spain and its heroes necessarily participated in the "translation" of Spanish culture for nineteenth-century British audiences that Saglia speaks of. But it also inevitably contributed to widening the gap between Spain and Portugal in British perceptions of the Iberian nations. And if the view of Spain as "the exemplary text of nationalism" 79 that these works helped promote was not the only one Britons subscribed to, it was the dominant one in the earlier moments of the war, the perceived relative importance of the two countries having initially been established by the Reviews, and solidified by the prose commentaries of the Lake poets that

77. Hemans did translate a short section from the fifth book of Camoens's epic The Lusiad, "Appearance of the Spirit of the Cape to Vasco da Gama." (See Iolanda Freitas Ramos and Isabel Cruz Lousada, "Traduções de Os Lusíadas em Inglaterra," in Camões em Inglaterra, ed. Maria Leonor Machado (Lisboa: Ministério da Educação, 1992), 7-63. Published in I840 in the volume The Sceptic: a Tale of the Secret Tribunal. The Siege of Valencia and Other Poems, this translation celebrates Portugal's maritime achievements; however, and like Hemans's other works inspired by Portuguese history, it was published well after the war. For example, "The Coronation of Inez de Castro," a poem inspired by the tragic love between Portugal's king Pedro and Inez de Castro, which she could have read about in Camoens's epic, was first published in I828 in The Monthly Magazine and later included in the I830 volume Songs of the Affections. Two other works directly inspired by Portuguese history, "Sebastian of Portugal (a dramatic fragment)" and "Ode on the Defeat of Sebastian of Portugal (translated from the Spanish of Herrera)," first appeared in the I836 posthumous volume The Poetical Remains of the Late Mrs. Hemans prepared by her family shortly after her death.

78. Kelly, ed., Felicia Hemans, I96-97, nI and n2; 198, n2.

79. Saglia, Poetic Castles, 65 (my emphasis). 
followed. Certainly, as this essay has demonstrated, it was the view that most strongly shaped the literary legacy of the period, its force having all but naturalized Portugal's sidelining in discursive representations of the Peninsular War that contributed to emblematize Britain as a champion of liberty.

Old Dominion University

\section{Bibliography}

Almeida, Joselyn M. "Introduction: Of Windmills and New Worlds." In Romanticism and the Anglo-Hispanic Imaginary, edited by Joselyn Almeida, 9-22. New York: Rodopi, 2010.

Bainbridge, Simon. "A Self-Defeating Campaign." In Concerning the Convention of Cintra: A Critical Edition, edited by Simon Bainbridge, W. J. B. Owen, and Richard Gravil, 30-33. Penrith: Humanities E-Books, 2009.

Behrendt, Stephen C. "Felicia Hemans's Early Reception." In Felicia Hemans: Reimagining Poetry in the Nineteenth Century, edited by Nanora Sweet and Julie Melnyk, 95-II4. New York: Palgrave, 200I.

Bernhardt-Kabisch, Ernest. Robert Southey. Boston: Twaine, I977.

Bromwich, David. "Vicarious Feeling: Spanish Independence, English Liberty." In Concerning the Convention of Cintra: A Critical Edition, edited by Simon Bainbridge, W. J. B. Owen, and Richard Gravil, 34-42. Penrith: Humanities E-Books, 2009.

[Brougham, Henry]. "Don Pedro Cevallos on the French Usurpation of Spain." The Edinburgh Review I3, no. 25 (October I808): 215-34.

Byron, George Gordon, Lord. Childe Harold's Pilgrimage. The Poetical Works of Lord Byron. London: Oxford University Press, 1946.

Cabral, Adolfo de Oliveira, ed. Southey e Portugal, 1774-1801: Aspectos de uma Biografia Literária. Lisbon: P. Fernandes, I959.

Carnall, Geoffrey. Robert Southey and His Age: the Development of a Conservative Mind. Oxford: Clarendon, I960.

Chittick, Kathryn. The Language of Whiggism: Liberty and Patriotism, 1802-1830. London: Pickering \& Chatto, 2010.

Clarke, John. Preface to Três Diários de Viagem: Portugal em 1808-1809, by Lord and Lady Holland, and John Allen. Notas e introdução de José Baptista de Souza. Casal de Cambra: Caleidoscópio, 20 I. 
Coleman, Deirdre. "Re-Living Jacobinism: Wordsworth and the Convention of Cintra." The Yearbook of English Studies I9 (I989): I44-6I.

Coleridge, Samuel Taylor. Letters on the Spaniards. In Essays on his times in the Morning Post and the Courier. Vol. 3, The Collected Works, edited by David V. Erdman. London: Routledge \& Kegan Paul, I978.

Colley, Linda. Britons: Forging the Nation, 1707-1837. New Haven, CT: Yale University Press,I992.

Daly, Gavin. The British Soldier in the Peninsular War: Encounters with Spain and Portugal, 1808-1814. New York: Palgrave, 2013.

"A Dirty, Indolent, Priest-Ridden City: British Soldiers in Lisbon During the Peninsular War, I808-I8I3." History 94 (2009): 46I-82.

Dennis, John, ed. Robert Southey: the Story of his Life Written in his Letters. Boston: D. Lothrop, I887.

Duggett, Tom. "Wordsworth's Gothic Politics and the Convention of Cintra." The Review of English Studies, New Series 58, no. 234 (April 2007): I $86-2$ II.

Eastwood, David. "Robert Southey and the Meanings of Patriotism." Journal of British Studies 3I, no. 3 (I992): 265-87.

[Ellis, George and George Canning]. “Affaires d'Espagne.” Quarterly Review I, no. I (February I809): I-I9.

Favret, Mary. "War Correspondence: Reading Romantic War.” Prose Studies I9, no. 2 (I996): I73-85.

Folker, Brian. "Wordsworth's Visionary Imagination: Democracy and War." ELH 69 (2002): I67-97.

Gravil, Richard. "Wordsworth as Partisan." In Concerning the Convention of Cintra: A Critical Edition, I6-29, edited by Simon Bainbridge, W. J. B. Owen, and Richard Gravil. Penrith: Humanities E-Books, 2009.

Green, Georgina. "The People and the Poet Redeemed: William Wordsworth and the Peninsular Uprising." ELH 79, no. 4 (20I 2): 935-62.

Guimarães, Paula Alexandra. "The Rescue of Lusia by Albion: Representations of Portugal in British Women's Peninsular Poetry." Revista de Estudos Anglo-Portugueses 25 (2016): I47-66.

Haywood, Ian. “The Spanish 'Revolution' in Print and Image." In Spain in British Romanticism, edited by Diego Saglia and Ian Haywood, 2I5-40. New York: Palgrave McMillan, 2018. 
Hemans, Felicia. The Domestic Affections. New York: Woodstock Books, I995.

- Poems: England and Spain; or, Valour and Patriotism, and Modern Greece. With an Introduction by Donald Hemman. New York: Garland, I978.

Holland, Lord and Lady, and John Allen. Três Diários de Viagem: Portugal em 1808-1809. Notes and introduction by José Baptista de Souza. Casal de Cambra: Caleidoscópio, 201 I.

Kelly, Gary. "Introduction," in Felicia Hemans: Selected Poems, Prose, and Letters, edited by Gary Kelly, I5-89. Peterborough: Broadview, 2002.

Kim, Benjamin. Wordsworth, Hemans, and Politics, 1800-1830: Romantic Crisis. Lewisburg, PA: Bucknell University Press, 20I3.

Manning, Peter. Reading Romantics: Texts and Contexts. New York: Oxford University Press, I990.

Monteiro, George. The Presence of Camões: Influences on the Literature of England, America, and Southern Africa. Lexington, KY: University Press of Kentucky, I996.

Mourão, Manuela. "Robert Southey on Portugal: Travel Narrative and the Writing of History." Nineteenth-Century Contexts 37, no. I (2015): 43-60.

Quillinan, Dorothy Wordsworth. Journal of a Few Months Residence in Portugal and Glimpses of the South of Spain. 2 vols. London: Edward Moxon, I847.

Ramos, Iolanda Freitas and Isabel Cruz Lousada. "Traduções de Os Lusíadas em Inglaterra." In Camões em Inglaterra, edited by Maria Leonor Machado, 7-63. Lisboa: Ministério da Educação, I992.

[Robinson, Henry Crabb]. "On the Spanish Revolution." London Review 2, no. 4 (Nov. I, I809): 23I-75.

Robson, Martin. "British Intervention in Portugal, I793-I808." Historical Research 76, no. I9I (2003): 93-I07.

Saglia, Diego. "Epic or Domestic?: Felicia Hemans's Heroic Poetry and the Myth of the Victorian Poetess." Rivista di Studi Vittoriani 2, no. 4 (I997): I $25-47$.

. "Nationalist Texts and Counter-Texts: Southey's Roderick and the Dissensions of the Annotated Romance." Nineteenth-Century Literature 53, no. 4 (March I999): 42I-5I.

—_ “'O My Mother Spain!': the Peninsular War, Family Matters, and the Practice of Romantic Writing." ELH 65, no. 2 (I998): 363-93. 
Poetic Castles in Spain: British Romanticism and Figurations of Iberia. Amsterdam: Rodopi, 2000.

"Robert Southey's Chronicle of the Cid: Spain as a Textual Archive and an Intervention Zone." Cuadernos de Ilustración y Romanticismo I8 (2012): $39-53$.

."War Romances, Historical Analogies and Coleridge's Letters on the Spaniards." In Romantic Wars: Studies in Culture and Conflict, 1793-1822, edited by Philip Shaw, I38-60. Aldershot: Routledge, 2000.

Sánchez, Juan. "England and Spain and The Domestic Affections: Felicia Hemans and the Politics of Literature." Studies in Romanticism 53, no. 3 (2014): 399-4I6.

[Scott, Walter]. "Chronicle of the Cid Rodrigo Diaz de Bivar, the Campeador, from the Spanish, by Robert Southey." Quarterly Review I, no. I (February i809): I34-35.

Southey, Robert. The Chronicle of the Cid. London: Longman, Hurst, Rees, and Orme, I808.

[- ]. The Edinburgh Annual Register for 1809. Edinburgh: John Ballantyne, I8II.

- History of the Peninsular War, 3 vols. London: John Murray, I823.

- Letters Written During a Short Residence in Spain and Portugal. With Some Accounts of Spanish and Portuguese Poetry. Bristol: Joseph Cottle, I797.

- Life and Correspondence of Robert Southey. Edited by Charles Southey. New York: Harper and Brothers, I85I.

- Roderick, the Last of the Goths. London: Longman, Hurst, Rees, Orme, and Brown, I8I 4 .

Speck, W. A. Robert Southey: Entire Man of Letters. New Haven, CT: Yale University Press, 2006.

Sweet, Nanora. "The Bowl of Liberty: Felicia Hemans and the Romantic Mediterranean.” PhD. Diss., University of Michigan, I993.

- and Julie Melnyk, eds. Felicia Hemans: Reimagining Poetry in the Nineteenth Century. New York: Palgrave, $200 \mathrm{I}$.

Valladares, Susan. "'For the sake of illustrating principles': Wordsworth, the Convention of Cintra, and Satirical Prints." European Romantic Review 24, no. 5 (20I3): $53 \mathrm{I}-54$. 
Vincent, Patrick. "Sleep or Death? Republicanism in The Convention of Cintra." In Concerning the Convention of Cintra: A Critical Edition, edited by Simon Bainbridge, W. J. B. Owen, and Richard Gravil, 53-62. Penrith: Humanities E-Books, 2009.

Wordsworth, William. Tract on the Convention of Cintra [Published 1809]. With two Letters of Wordsworth Written in the Year 1811 Now Republished. With an Introduction by $A$. $V$. Dicey. London: Humphrey Milford, I9I5. 